\title{
CHALLENGES IN ADOPTION OF NEW TECHNOLOGIES IN BANKING SECTOR - A STUDY WITH REFERENCE TO SELECTED PRIVATE BANKS, BENGALURU
}

\author{
Ramya Reddy $\mathbf{P}$ \\ II Year MBA, Faulty of Management and Commerce, \\ Ramaiah University of Applied Sciences, Bengaluru, India \\ Rakesh C \\ Assistant Professor and Head, Department of Commerce, Faulty of Management and \\ Commerce, Ramaiah University of Applied Sciences, Bengaluru, India
}

\begin{abstract}
The main aim of this research was to carry out an analysis on impact of new technologies in private banks refer to consumers Perception. A background study has been carried out to understand the factors that are affecting the new technologies in private banks. A survey was conducted to 225 respondents from 5 private banks ICICI Bank, HDFC Bank, Axis Bank, IndusInd Bank, IDBI Bank. The research results found that respondents have started using new technologies and are satisfied with the services provided by their banks and digital India played an important role in shaping the new era in banking sector and move towards the cashless economy. It was found that most of them told that watch banking is expensive to use and only few banks offer this service to customers.
\end{abstract}

Key word: BHIM UPI, Cashless Economy, Digitalisation, E-wallets, Innovations, New technologies, Private banks, Quality Services

Cite this Article: Ramya Reddy P, Rakesh C, Challenges in Adoption of New Technologies in Banking Sector - A Study with Reference to Selected Private Banks, Bengaluru, International Journal of Management, 10 (4), 2019, pp. 173-181.

$\mathrm{http}: / /$ iaeme.com/Home/issue/IJM?Volume $=10 \&$ Issue $=4$

\section{INTRODUCTION}

After banking reforms, the private banks started increasing rapidly in early 1990's the banking sector has been showing new heights in banking technologies, private banks started modern banking in India to attract larger sector of the public. They not only give good interest rates for the customers but also, they provided many services to their customers. These private sector banks provided more comfortable and luxury services to their customers. These private banks always concentrate on the customers satisfaction and always try the reach the expectations and they keep eye on customers' needs and wants. Later private banks started online transactions 
facilitates to their customers and started providing online banking applications to them. After the increase in smartphones usage in the public there were many online applications that have come in the market for the payment methods. These payment applications have brought huge difference to customers preferences. And these applications have given more comfort to the customers for using it for various payments like transaction of money through online from any ever at any time without going to the bank and depositing the money and these applications have done the work more easier for online shopping and paying cash in any restaurants, departmental stores by scanning QR (Quick response) code and pay without hard cash. These payment methods have been increasing rapidly in present generation, as Indian government wants Indian public to go for digital methods for payments and transactions. Indian government is trying to make India a cashless economy. India has started a programme called "Digital India" were they except people to use digital methods for transactions and payment which makes our country standards high in the international level, we have seen different types of applications coming to the market after the government announced "Demonetisation". After Demonetisation happened in India on 8th November 2106 public had faced lots of problem in transaction of money, payment for buying their daily needs in those time these online applications like PayTM played an important role in making the peoples life easy and later the usage of these applications started booming in the country. Later these digital wallets have taken all over the country.

\section{LITERATURE REVIEW}

The major difficulty faced by the users in using these digital wallets is security. Digital wallets are mostly dependent on internet and that is giving a negative impact on adopting them. There must be an awareness program to overcome these problems. (Dr. Hem Shweta Rathore, 2015). The author found that the major factor the is influencing is mobile banking and among all the factor social impact is least affecting factor. This study is done so, that banks can understand the intentions of consumers and bring new strategies to ensure the financial inclusion. (Amith Shankar and Pooja Kumari, 2016). The author tells that in present generation smart phones are playing an important role in people's daily life and the usage of mobile wallet awareness as rapidly spread among the people in the country after demonetisation and this government policy made people to use mobile wallets forcefully. If the security issues are addressed properly then the adoption of mobile wallets will automatically increase. (Dr. S. Manikandan,2017). This paper main aim is to study the impact of economic reform on banking sector. This paper tells that the Indian economy has been running with progressive growth after 1990's due to implementation of economic reforms banking sector has seen greater progress. Indian banking sector is one of the most important sectors among all the service sectors in the country and banking also know for measuring the financial performances of the country and the economic growth and sustainability because banking is known as economic barometer. (Sri. T. Balayya, 2016). This research aim is to know whether the cashless economy in rural areas a dream or reality is. This paper tells that about more than $50 \%$ of India population is dependent on agriculture and being an agrarian economy, the agriculture productions and distributions are highly dependent on cash transactions. The paper found that most of farmers do not use any digital mode for transacting money as they are far from using internet banking because no proper internet services in areas and most for them prefer using hard cash as they feel it is safe and secure. The author suggests that even if one person in the rural area gets benefits by using digital payment then the rest will try to fellow. (Sheetal Thomas, 2017). The aim of this research is to find explore the relationship between financial sector reforms and the emergence of digital banking culture in India. The paper found that digital banking will help people in reducing the cost, risk and saves time and helps in maintaining transparency between banks and customers. For this to happen it is important that financial sector reforms should met the innovation and technologies in banking sector, does it is very important for timing the financial 
sector reforms is very crucial. (Aijaz A. Shaikh, 2017). This paper tells about the digital payments and what happened after demonetization in India and how did people started using the digital modes for payments. This paper found that after demonetization people didn't had hard cash in their hands and most of the people faced problem in buying their daily needs. This problem forced most of the people to use digital method for the payments. Later people felt that digital payments are more convenient and easier for using and they continued using digital payment modes. (Dorothy Sagayarani, 2017). At presently the internet banking is rapidly increasing and people slowly adopting this mode but still there are certain people not using this mode for transactions due to trust issues and some does not know to use these new technologies (senior citizens). (Dr. Karuna Gupta, 2017). The study found that people in metropolitan cities are using e-wallets compared to other small cities and with every unit that brought change in awareness among the digital payment system and there are $2.069 \%$ chances of users adopting digital payment mode. (Alakanda Lonare, 2018).

\section{METHODOLOGY}

\subsection{Primary Source of Data}

Primary data is basically collected by conducting interviews, asking questions or creating questionnaires and breaking down certain data, and so on. The primary data collected for this dissertation is creating questionnaires and examination. Data was collected from around 225 respondents of private bank account holders in Bangalore.

\subsection{Secondary source of data}

Secondary data is basically the information collected from various websites, thesis, published Journals, identified articles, books, magazines, new papers and many more. This secondary data gathered for this dissertation is published journals, identified articles, thesis, internet sources and books.

\section{DATA ANALYSIS}

Table.1: Transactions in UPI and E-Wallets are limited for certain amount

\begin{tabular}{|c|l|c|c|c|c|}
\hline \multicolumn{2}{|c|}{} & Frequency & Percent & $\begin{array}{c}\text { Valid } \\
\text { Percent }\end{array}$ & $\begin{array}{c}\text { Cumulative } \\
\text { Percent }\end{array}$ \\
\hline \multirow{4}{*}{ Valid } & strongly Disagree & 9 & 4 & 4 & 4 \\
\cline { 2 - 6 } & Disagree & 12 & 5.3 & 5.3 & 9.3 \\
\cline { 2 - 6 } & Neutral & 24 & 10.7 & 10.7 & 20 \\
\cline { 2 - 6 } & Agree & 104 & 46.2 & 46.2 & 66.2 \\
\cline { 2 - 6 } & Strongly Agree & 76 & 33.8 & 33.8 & 100 \\
\cline { 2 - 6 } & Total & 225 & 100 & 100 & \\
\hline
\end{tabular}

The Above table tells about how respondent reacted for Transactions in UPI and E-Wallets are limited for certain amount (can't transact in Lakhs) for which 4\% of respondents tells that they Strongly Disagree with the statement and 5\% of respondents Disagree with it and about $11 \%$ of respondents tells that they are neutral and where as $46 \%$ respondents Agree with this and 34\% respondents Strongly Agree with the statement.

Table.2: UPI and E-Wallets are promoting cashless economy

\begin{tabular}{|l|l|c|c|c|c|}
\hline \multicolumn{2}{|l|}{} & Frequency & Percent & $\begin{array}{c}\text { Valid } \\
\text { Percent }\end{array}$ & $\begin{array}{c}\text { Cumulative } \\
\text { Percent }\end{array}$ \\
\hline Valid & strongly Disagree & 6 & 2.7 & 2.7 & 2.7 \\
\hline
\end{tabular}


Challenges in Adoption of New Technologies in Banking Sector - A Study with Reference to Selected Private Banks, Bengaluru

\begin{tabular}{|l|l|c|c|c|c|} 
& Disagree & 4 & 1.8 & 1.8 & 4.4 \\
\cline { 2 - 5 } & Neutral & 30 & 13.3 & 13.3 & 17.8 \\
\cline { 2 - 5 } & Agree & 119 & 52.9 & 52.9 & 70.7 \\
\cline { 2 - 5 } & Strongly Agree & 66 & 29.3 & 29.3 & 100 \\
\cline { 2 - 5 } & Total & 225 & 100 & 100 & \\
\hline
\end{tabular}

The Above table tells about how respondent reacted for UPI and E-Wallets are promoting cashless economy for which 3\% of respondents tells that they Strongly Disagree with the statement and $2 \%$ of respondents Disagree with it and about $13 \%$ of respondents tells that they are neutral and where as 53\% respondents Agree with this and 29\% respondents Strongly Agree with the statement.

Table.3 They provide immediate solutions for the problem related to the transactions

\begin{tabular}{|l|l|c|r|c|c|}
\hline \multicolumn{2}{|c|}{} & Frequency & Percent & $\begin{array}{l}\text { Valid } \\
\text { Percent }\end{array}$ & $\begin{array}{l}\text { Cumulative } \\
\text { Percent }\end{array}$ \\
\hline \multirow{5}{*}{ Valid } & strongly Disagree & 65 & 28.9 & 28.9 & 28.9 \\
\cline { 2 - 6 } & Disagree & 73 & 32.4 & 32.4 & 61.3 \\
\cline { 2 - 6 } & Neutral & 40 & 17.8 & 17.8 & 79.1 \\
\cline { 2 - 6 } & Agree & 35 & 15.6 & 15.6 & 94.7 \\
\cline { 2 - 6 } & Strongly Agree & 12 & 5.3 & 5.3 & 100 \\
\cline { 2 - 6 } & Total & 225 & 100 & 100 & \\
\hline
\end{tabular}

The Above pie chart tells about how respondent reacted for They provide immediate solutions for the problem related to the transactions (like twice debited) for which $29 \%$ of respondents tells that they Strongly Disagree with the statement and 32\% of respondents Disagree with it and about $18 \%$ of respondents tells that they are neutral and where as $16 \%$ respondents Agree with this and 5\% respondents Strongly Agree with the statement.

Table.4 Watch banking is more expensive to use

\begin{tabular}{|c|l|c|c|c|c|}
\hline \multicolumn{2}{|c|}{} & Frequency & Percent & $\begin{array}{c}\text { Valid } \\
\text { Percent }\end{array}$ & $\begin{array}{c}\text { Cumulative } \\
\text { Percent }\end{array}$ \\
\hline \multirow{5}{*}{ Valid } & strongly Disagree & 1 & 0.4 & 0.4 & 0.4 \\
\cline { 2 - 6 } & Disagree & 8 & 3.6 & 3.6 & 4 \\
\cline { 2 - 6 } & Neutral & 44 & 19.6 & 19.6 & 23.6 \\
\cline { 2 - 6 } & Agree & 133 & 59.1 & 59.1 & 82.7 \\
\cline { 2 - 6 } & Strongly Agree & 39 & 17.3 & 17.3 & 100 \\
\cline { 2 - 6 } & Total & 225 & 100 & 100 & \\
\hline
\end{tabular}

The Above pie chart tells about how respondent reacted for Watch banking is more expensive to use for which None of the respondents tells that they Strongly Disagree with the statement and $4 \%$ of respondents Disagree with it and about $20 \%$ of respondents tells that they are neutral and where as 59\% respondents Agree with this and 17\% respondents Strongly Agree with the statement.

Table.5 Watch banking is not offered by many banks

\begin{tabular}{|c|l|c|c|c|c|}
\hline \multicolumn{2}{|c|}{} & Frequency & Percent & $\begin{array}{c}\text { Valid } \\
\text { Percent }\end{array}$ & $\begin{array}{c}\text { Cumulative } \\
\text { Percent }\end{array}$ \\
\hline \multirow{4}{*}{ Valid } & strongly Disagree & 4 & 1.8 & 1.8 & 1.8 \\
\cline { 2 - 6 } & Disagree & 9 & 4 & 4 & 5.8 \\
\cline { 2 - 6 } & Neutral & 41 & 18.2 & 18.2 & 24 \\
\cline { 2 - 6 } & Agree & 139 & 61.8 & 61.8 & 85.8 \\
\cline { 2 - 6 } & Strongly Agree & 32 & 14.2 & 14.2 & 100 \\
\hline
\end{tabular}


The Above pie chart tells about how respondent reacted for Watch banking is not offered by many banks for which 2\% of respondents tells that they Strongly Disagree with the statement and $4 \%$ of respondents Disagree with it and about $8 \%$ of respondents tells that they are neutral and where as $62 \%$ respondents Agree with this and 14\% respondents Strongly Agree with the statement.

Table.6 Coral cards are making our payment methods easy

\begin{tabular}{|c|l|c|c|c|c|}
\hline \multicolumn{2}{|c|}{} & Frequency & Percent & $\begin{array}{c}\text { Valid } \\
\text { Percent }\end{array}$ & $\begin{array}{c}\text { Cumulative } \\
\text { Percent }\end{array}$ \\
\hline \multirow{5}{*}{ Valid } & strongly Disagree & 3 & 1.3 & 1.3 & 1.3 \\
\cline { 2 - 6 } & Disagree & 4 & 1.8 & 1.8 & 3.1 \\
\cline { 2 - 6 } & Neutral & 35 & 15.6 & 15.6 & 18.7 \\
\cline { 2 - 6 } & Agree & 142 & 63.1 & 63.1 & 81.8 \\
\cline { 2 - 6 } & Strongly Agree & 41 & 18.2 & 18.2 & 100 \\
\cline { 2 - 6 } & Total & 225 & 100 & 100 & \\
\hline
\end{tabular}

The Above pie chart tells about how respondent reacted for Coral cards are making our payment methods easy for which $1 \%$ of respondents tells that they Strongly Disagree with the statement and $2 \%$ of respondents Disagree with it and about $16 \%$ of respondents tells that they are neutral and where as 63\% respondents Agree with this and 18\% respondents Strongly Agree with the statement.

Table.7 There is security threat in using coral cards

\begin{tabular}{|c|l|c|c|c|c|}
\hline \multicolumn{2}{|c|}{} & Frequency & Percent & $\begin{array}{c}\text { Valid } \\
\text { Percent }\end{array}$ & $\begin{array}{c}\text { Cumulative } \\
\text { Percent }\end{array}$ \\
\hline \multirow{5}{*}{ Valid } & strongly Disagree & 5 & 2.2 & 2.2 & 2.2 \\
\cline { 2 - 6 } & Disagree & 19 & 8.4 & 8.4 & 10.7 \\
\cline { 2 - 6 } & Neutral & 83 & 36.9 & 36.9 & 47.6 \\
\cline { 2 - 6 } & Agree & 102 & 45.3 & 45.3 & 92.9 \\
\cline { 2 - 6 } & Strongly Agree & 16 & 7.1 & 7.1 & 100 \\
\cline { 2 - 6 } & Total & 225 & 100 & 100 & \\
\hline
\end{tabular}

The Above pie chart tells about how respondent reacted for the security threat in using coral cards for which $2 \%$ of respondents tells that they Strongly Disagree with the statement and 9\% of respondents Disagree with it and about $37 \%$ of respondents tells that they are neutral and where as 45\% respondents Agree with this and 7\% respondents Strongly Agree with the statement.

Table.8 Digital India played a key role for the implementation of new banking technologies in India

\begin{tabular}{|c|l|c|c|l|l|}
\hline \multicolumn{2}{|c|}{} & Frequency & Percent & $\begin{array}{l}\text { Valid } \\
\text { Percent }\end{array}$ & $\begin{array}{l}\text { Cumulative } \\
\text { Percent }\end{array}$ \\
\hline \multirow{3}{*}{ Valid } & Yes & 218 & 96.9 & 96.9 & 96.9 \\
\cline { 2 - 6 } & No & 7 & 3.1 & 3.1 & 100 \\
\cline { 2 - 6 } & Total & 225 & 100 & 100 & \\
\hline
\end{tabular}

The Above pie chart tells about how respondent reacted for Digital India played a key role for the implementation of new banking technologies in India for which $97 \%$ respondents 
Challenges in Adoption of New Technologies in Banking Sector - A Study with Reference to Selected Private Banks, Bengaluru

reacted Yes, digital India as an impact on new technologies in banking sector where as 3\% of respondents reacted No, digital India does not impact on new technologies in banking sector.

\subsection{Correlation Test}

Here, in this research correlation test is done to check whether there is a relationship between two variables

Table.9 H1: Cash backs are the main reason for using E-Wallets after Demonetisation

\begin{tabular}{|l|l|c|c|}
\hline \multicolumn{2}{|c|}{} & $\begin{array}{c}\text { Cash backs reason } \\
\text { for using E-Wallets }\end{array}$ & $\begin{array}{c}\text { Using after } \\
\text { demonetisation }\end{array}$ \\
\hline \multirow{3}{*}{$\begin{array}{l}\text { Cash backs reason for using } \\
\text { E-Wallets }\end{array}$} & $\begin{array}{l}\text { Pearson } \\
\text { Correlation }\end{array}$ & 1 & $.504^{* *}$ \\
\cline { 2 - 4 } & Sig. (2-tailed) & & .000 \\
\cline { 2 - 4 } & $\mathrm{N}$ & 225 & 225 \\
\hline Using after demonetization & $\begin{array}{l}\text { Pearson } \\
\text { Correlation }\end{array}$ & $.504^{* *}$ & 1 \\
\cline { 2 - 4 } & Sig. (2-tailed) & .000 & 225 \\
\cline { 2 - 4 } & $\mathrm{N}$ & 225 & \\
\hline
\end{tabular}

Ho: Null hypothesis is rejected

HA: Alternative hypothesis is accepted. This hypothesis shows that there is positive correlation between the cash backs for using E-Wallets and using E-Wallets after demonetization. The pvalue is 0.01 , which indicates that there is significant relationship between the two selected variables. Hence, it clearly shows that the two variables support the hypothesis and there exists a relation between the cash backs and demonetization for using E-Wallets.

Table.10 H2: E-Huts can give faster solution that makes everyone's work easier

\begin{tabular}{|l|l|c|c|}
\hline \multicolumn{2}{|c|}{} & $\begin{array}{c}\text { E-Huts can be } \\
\text { faster solution }\end{array}$ & $\begin{array}{c}\text { E-Huts make } \\
\text { our work } \\
\text { easier }\end{array}$ \\
\hline \multirow{2}{*}{ E-Huts can be faster solution } & $\begin{array}{l}\text { Pearson } \\
\text { Correlation }\end{array}$ & 1 & $.460^{* * *}$ \\
\cline { 2 - 4 } & Sig. (2-tailed) & & .000 \\
\cline { 2 - 4 } & $\mathrm{N}$ & 225 & 225 \\
\hline E-Huts make our work easier & $\begin{array}{l}\text { Pearson } \\
\text { Correlation }\end{array}$ & $.460^{* *}$ & 1 \\
\cline { 2 - 4 } & Sig. (2-tailed) & .000 & \\
\cline { 2 - 4 } & $\mathrm{N}$ & 225 & 225 \\
\hline
\end{tabular}

Ho: Null hypothesis is rejected

HA: Alternative hypothesis is accepted. This hypothesis shows that there is positive correlation between E-Huts can be faster solution and makes our work easier. The p-value is 0.01 , which indicates that there is significant relationship between the two selected variables. Hence, it clearly shows that the two variables support the hypothesis and there exists a relation between the faster solution and makes our work easier in using E-Huts.

\section{DISCUSSIONS}

The identified factors that affecting the new technologies in private banks are watch banking, E-Deposits, BHIM UPI, E-Wallets, Coral cards, E-Huts. The research found that factor that influenced consumers to adopt new technologies are digital India programme, Demonetisation, 
Cashless economy programme. Around $32 \%$ and $29 \%$ of the respondents Disagree and Strongly Disagreed that these E-Wallets and UPI application provide immediate solutions for their problems related to transactions like twice debited but whereas these applications do not refund and even if they assure for the refund they take minimum 2-3 working weeks to do it because of this many of them are facing problem using these applications. 59\% and $17 \%$ of the respondents Agreed and Strongly Agreed respectively that watch banking is expensive to use because Apple watches (iWatches) and Samsung watches are very costly to buy, these watches can't be affordable by everyone. So, most of the respondents feel that watch banking is expensive to use. And again $62 \%$ and $14 \%$ of respondents Agreed and Strongly Agreed respectively that watch banking is not offered by many banks as the bank don't feel that most of the people can't use watch banking as it is expensive to buy smart watches. Respondents have expressed different answers when asked that using bank online application is better than using other applications. Here is there response $9 \%$ of the strongly disagree that bank application is better and $29 \%$ of them responded that they disagree with it but $23 \%$ of them remained neutral but whereas $29 \%$ of the agreed that it is better to use bank application and $10 \%$ of them strongly agreed with it. This tells that some people don't like to take any risk and they feel but to use bank application as their bank will respond soon if something will go wrong while transactions. $46 \%$ and $35 \%$ of them Agreed and Strongly Agreed respectively that in EWallets and BHIM UPI they cannot transact more money like in Lakhs because there is certain limit for transacting money in these applications i.e., in BHIM UPI one can transfer maximum of 40,000 per person and in E-wallet application a maximum number of 10 transaction of 1 lakh is the limit. In addition, if any one wants to transfer more money, they should use IMPS and NEFT.

Digital India, Cashless economy programmes made people to switch to digital payments, if government will be able to do such innovative programmes it would be great for future. Banks can install E-Depository machines beside their ATM's, minimum one machine in every area which will make customers to deposit their money in these E-Deposits without any problem. Transactions in E-wallets and BHIM UPI applications can extend their limited of

transaction of money which will make better for people to transfer money without any difficulty. E-Wallets and UPI applications should try to refund the customers money as soon as possible if its debited twice but not credit, as these applications take longer time for fixing the problem. Coral cards should be used be used in local stores, super markets which will make customers comfortable to pay the bill. Respondents want banks to launch E-Huts which will be help full for them to solve their problem in one step without any difficulty, hope the banks to launch this application soon. As the new technologies and innovations have taken the world on storm, in future we may witness that information technology companies may launch smart watches which can be affordable by customers, that may help in increasing the usage of watch banking.

\section{LIMITATIONS}

The study has focused on only few variables the future study can use different variable like API, block chain, beacon technology. The survey was conducted for only private bank account holders particularly to ICICI bank, HDFC bank, IndusInd bank, Axis bank, IDBI bank

\section{CONCLUSION}

Many changes have happened in banking sector after the financial reforms (banking reforms) in the past few years. In the present era the new technologies have changes the face banking system, like standing in the queue for depositing or drawing money to transacting money from anywhere at any time. Indian banking has shown new heights in the past few years and 
Government programmes have helped banks to come up with new technologies in banking sector. In the present generation many private banks have started using new technologies to provide better services for their customers, these new modes of services have brought better life style to the customers. Public is completely satisfied by the services provided by the banks but there are certain problems too, One of the problems faced by the customers is that in digital wallet applications does not provide immediate solution for the problems related to the transactions like twice debited but not credited, these applications take minimum of 2-3 weeks to solve the problem. It is suggested that the digital wallets applications should try to respond quickly to the customers and fix the problem as soon as possible, by doing this customer will build the trust in using new technologies. And the adoption of new technology has been good by far the banks and customers are extremely satisfied by these new innovations or technologies but ultimately there must be proper security for online transactions and the Indian Banking Industry has shown considerable resilience during the return period The second-generation returns will play a crucial role in further strengthening the system New technology has particularly been both enabled and in turn fueled by a huge influx of new providers and products, all vying to enter the payments space

\section{REFERENCES}

[1] Rathore, H.S.,Adoption of digital wallet by consumers. BVIMSR's Journal of Management Research, 8(1), 2016, p.69.

[2] Shankar, A. and Kumari, P.,Factors affecting mobile banking adoption behavior in India. The Journal of Internet Banking and Commerce, 21(1), 2016

[3] Dr. V. Antony Joe Raja and V. Vijayakumar, A Study on Stress Management among the Different Type of Working Employees of Banking Sector with Skill Development Orientation Solution in India. International Journal of Marketing and Human Resource Management, 8(1), 2017, pp. 13-17.

[4] Manikandan, S. and Jayakodi, J.M., An empirical study on consumer adoption of mobile wallet with special reference to Chennai city. International Journal of Research-Granthalaya, 5(5), 2017, pp.107-115.

[5] Sri. T, Balayya. impact of Economic Reforms on Banking Sector, Liberalization. Journal of Business and Management, 2016, pp. 62-66.

[6] Dr. C. Mahadeva Murthy and Prof. S.N. Pathi, An Assessment of Risk Management in Banking Sector: A Study with Special Reference to Public and Private Sector Banks in India, International Journal of Advanced Research in Management (IJARM), Volume 4, Issue 3, September - December 2013

[7] Thomas, S. and Krishnamurthi, G., Cashless rural economy-a dream or reality?. Jharkhand Journal of Development and Management Studies XISS, Ranchi, 15(2), 2017, pp.7269-7281.

[8] S. Visalakshmi, Dr. R. Ratneswary V. Rasiah, Impact of Disruptive Technology on Indian Banking Sector, International Journal of Mechanical Engineering and Technology 8(9), 2017, pp. 510-515.

[9] Shaikh, A., Glavee-Geo, R. and Karjaluoto, H, Exploring the nexus between financial sector reforms and the emergence of digital banking culture - Evidences from a developing country. Research in International Business and Finance, 42, 2017, pp.1030-1039.

[10] Sagayarani, D.,Digital payments in India. IOSR Journal of Business and Management (IOSR-JBM), 2017, PP 28-33

[11] Dr. R. Perumal And M. Pradeeba, Self-Management Among Managers and Its Impact on Non-Managerial Employees' Job Satisfaction in The Banking Sector, International Journal of Advanced Research in Management (IJARM), Volume 5, Issue 6, November-December (2014), pp. 04-12 
[12] Gupta, K., Arya, R. and Goel, V.,Emerging trends in banking sector in India: with special reference to digitization. Int J Sci Technol Manage, 6(3), 2017, pp.260-268.

[13] Lonare, A., Yadav, A. and Sindhu, S., E-Wallets: Diffusion and Adoption in Indian Economy. Indian Journal of Commerce and Management Studies, 9(2), 2018, pp.9-16. 